\title{
Factors on Mustahiq's Business Performance Through Productive Zakah at the Baznas in Kalimantan Timur Province
}

\author{
Sri Wahyuni ${ }^{1}$, Syarifah Hudayah ${ }^{2}$ \\ Faculty of Economic and Business, Mulawarman University, Indonesia \\ ${ }^{1}$ wahyuni_mumtaz@yahoo.co.id \\ ${ }^{2}$ syarifah.hudayahefeb.unmul.ac.id
}

\begin{abstract}
The Badan Amil Zakat Nasional Kalimantan Timur (Baznas Kaltim) is one of the institutions that play an important role in developing the economy in Kalimantan Timur Province, especially in alleviating poverty. Therefore, the Baznas Kaltim needs to give the distribution of zakat fairly to mustahiq. Mustahiq who receives zakat every year is given special coaching in developing entrepreneurship. The purpose of this study is to analyze what factors affect business performance at mustahiq in East Kalimantan baznas. This research uses the method of naturalistic-qualitative research (naturalistic-qualitative research). The study uses unstructured interviews. There were five people who became informants in this study.

This study found that entrepreneurial spirit is very helpful in motivating in business development. Financing is the most important thing in developing a business. The financing is used for operational activities mustahiq. Interestingly, many mustahiq do not need technology in developing their business because of limited skills. So that required maximum assistance from BAZNAS Kaltim. Self-motivation mustahiq in work is very important in developing themselves and their business. In the work required the application of principles of efficiency and benefits while maintaining environmental sustainability. In addition, mustahiq expected to think to get the balance between the treasures with worship. So, after successful in work mustahiq should always be grateful to Allah SWT.
\end{abstract}

Keywords - mentoring, entrepreneurship, business performance, mustahiq.

\section{INTRODUCTION}

Kalimantan Timur before the expansion of the region is the second largest province in Indonesia after Papua. The main driver of the province's economy is mining activities such as oil, natural gas and coal, other sectors currently being developed are agriculture, tourism and processing industries. The total population of Kalimantan Timur are 3.6 million people (BPS, 2013) with employment covering 3 main sectors, namely agriculture sector covering agricultural business field, manufacturing industry sector covering mining/quarrying, industrial, electricity, gas and water drinking and service sectors including trade, restaurant and hotel, transportation, warehousing and communications, finance, insurance and so on.

In the effort to overcome the problem of poverty in Kalimantan Timur cannot fully expect in APBN or APBD, but also have to explore potency of other sources as mediation device such as one of them is from Zakat, Infaq and Shadaqah (ZIS) managed by the Badan Amil Zakat Nasional (Baznas) Of Kalimantan Timur, taking into account the existing potentials such as business development for communities with small and medium enterprises.

In accordance with Law Number 20 Year 2008 regarding Micro, Small and Medium Enterprises (MSMEs) is first. Micro Enterprises are productive business owned by individual business entity fulfilling the criteria of Micro Business as regulated in this Law. Secondly, Small-scale Business is a stand-alone productive economic enterprise, conducted by an individual or a business entity that is not a subsidiary or not a branch of a company owned, controlled, or becomes part of the direct or indirect business of a medium-sized or largeCriteria of Small Business as referred to in this Law. Third, Medium Enterprises are stand-alone productive economic enterprises, carried out by an individual or business entity that is not a subsidiary or branch of a company owned, controlled, or becomes part directly or indirectly with a Small Business or a large business with the amount of wealth Net or annual sales proceeds as provided in this Law.

Micro, small and medium enterprises (MSMEs) is the main sector contributing to the absorption of manpower in Indonesia. In 2013, MSMEs are able to absorb labor of $101,722,458$ people or $97.24 \%$ of the total absorption of existing workforce, this 
number increased by $0.02 \%$ or 2.182 .700 people compared to 2012. Small business contribution was recorded as much as $99,401.775$ people or $97.22 \%$. Approximately $99 \%$ of the total business units in Indonesia are UMKM-scale, and recorded to create employment of about 99.4 million workers. Meanwhile, large businesses absorb about 2.8 million workers (data from the Ministry of Cooperatives and Small and Medium Enterprises, 2013).

MSMEs are also considered to be very potential in increasing state revenues through taxes. The existence and role of SMEs in 2013 reached 55.21 million business units, and $99.99 \%$ of national business actors, in the national economic order is no doubt, by looking at its contribution in the absorption of labor, the formation of Gross Domestic Product (GDP) ) National, national foreign exchange, and national investment. The development of the number of SMEs in the period 2012-2013 increased by $2.57 \%$ from $53,823,732$ units in 2012 to 55,206,444 units in 2013. UMKM is the largest business actor with a percentage of $99.99 \%$ of the total national business actors on 2012 (UMKM Statistics, Kemenkop, 2013).

Development of Micro, Small and Medium Enterprises in Kalimantan Timur by the end of 2013 has increased considerably, Micro Business 35,339 units with an increase of turnover (in million) 52,233 (2012) to 89,935 (2013), Small Business 409,086 units with turnover of 99,140 (2012) 99,843 (2013) and Medium Enterprises 921 units with a turnover of $2,987,300$ (2012) to $3,030,018$ (2013). The Criteria of micro, small and medium enterprises are as follows:

TABLE I

\begin{tabular}{|l|l|l|l|}
\hline \multicolumn{1}{|c|}{ MICRO, SMALL AND MEDIUM ENTERPRISES CRITERIA } \\
\hline $\begin{array}{l}\text { Micro } \\
\text { Business }\end{array}$ & Small business & $\begin{array}{l}\text { Medium } \\
\text { Enterprises }\end{array}$ \\
\hline Assets & $\begin{array}{l}\text { Maximum 50 } \\
\text { million /year }\end{array}$ & $\begin{array}{l}50-500 \\
\text { million/year }\end{array}$ & $\begin{array}{l}500 \text { jt - 10 } \\
\text { million/year }\end{array}$ \\
\hline Revenues & $\begin{array}{l}\text { Maximum 300 } \\
\text { million/year }\end{array}$ & $\begin{array}{l}300-500 \\
\text { million/year }\end{array}$ & $\begin{array}{l}10-2,5 \\
\text { million/year }\end{array}$ \\
\hline $\begin{array}{l}\text { The total of } \\
\text { employee }\end{array}$ & Under 5 person & $5-19$ person & $\begin{array}{l}20-99 \\
\text { person }\end{array}$ \\
\hline
\end{tabular}

The Muslim community which become the perpetrators of SMEs categorized as mustahiq, ie eight asnaf who are given zakat assistance by the Agency of Amil Zakat (BAZ) both productively and consumptive, while the productive assistance has a good enough potential in increasing mustahiq to turn into muzakki (giver of zakat ). One of the problems in Indonesia that has not been successfully addressed by the government is the high level of poverty and the level of income gap. BPS (2016) data shows that the number of poor people in Indonesia is 28.51 million people or 11.26 percent, followed by high Gini index in Indonesia (0.41). If this problem continues to be allowed, then one of the effects of a prolonged inequality will hamper the welfare level of society.

The existence of different groups of income cannot be denied. To eliminate poverty alone quite a lot of efforts have been made, now is how to reduce and minimize the poverty rate that occurred. One of the pillars to minimize the poverty level by optimizing the utilization of productive zakat considering the amount of zakat potential in Indonesia reached $\mathrm{Rp} 217$ trillion (Beik and Arsyianti, 2016). Zakat productive channeled to micro business actors is one effort for community empowerment. Currently, the contribution of micro enterprises to Indonesia's GDP reaches Rp 807.8 trillion with the number of micro business units reaching 57.1 million units (Kemenkop UKM, 2013). This shows that productive zakat funds given to micro businesses have great potential in spurring economic growth and tackling poverty and gaps.

BAZ itself has a productive zakat distribution program to several districts/municipalities in East Kalimantan Province, but the program is managed and accompanied by each regency/city BAZ and reported collectively to Baznas Kaltim. While special for Samarinda region BAZ do assistance and Monitoring directly to the mustahiq recipients (Source: interview with Mr. Iksan Baznas, januari 2015). The data owned by Baznas in Kalimantan Timur against the mustahiq area of Samarinda City who are given zakat assistance for productive use as seen in Table II Mustahiq who are given zakat assistance for productive use can be categorized as micro and small business actor only, because seen 
from the criteria owned include both turnover, capital and the amount of labor is the criteria of micro and small enterprises, so this research will focus on the criteria And not on medium-sized enterprises.

TABLE II

THE TYPE OF MUSTAHIQ IN BAZNAS KALIMANTAN TimUR SAMARINDA IN 2011-2015

\begin{tabular}{|c|c|c|c|c|}
\hline No. & $\begin{array}{l}\text { Type } \\
\text { Mustahiq }\end{array}$ & \multicolumn{2}{|c|}{ Amount } & $\begin{array}{l}\text { The amount of } \\
\text { distribution (Rp) }\end{array}$ \\
\hline 1. & $\begin{array}{l}\text { Seller of Night } \\
\text { Market }\end{array}$ & \multirow{4}{*}{$\begin{array}{l}10 \\
4 \\
15 \\
5\end{array}$} & \multirow{2}{*}{$\begin{array}{l}\text { Persons } \\
\text { Persons }\end{array}$} & 20.000 .000 \\
\hline 2. & $\begin{array}{l}\text { Mushrooms } \\
\text { farmer }\end{array}$ & & & 8.000 .000 \\
\hline 3. & Seller & & \multirow{2}{*}{$\begin{array}{l}\text { Persons } \\
\text { Persons }\end{array}$} & 15.000 .000 \\
\hline 4. & Tailor & & & 10.000 .000 \\
\hline 5. & $\begin{array}{l}\text { Fishermen in } \\
\text { Mugirejo }\end{array}$ & \multirow{2}{*}{$\begin{array}{l}5 \\
3\end{array}$} & \multirow{2}{*}{$\begin{array}{l}\text { Persons } \\
\text { Persons }\end{array}$} & 12.500 .000 \\
\hline 6. & UKM Kerupuk & & & 3.000 .000 \\
\hline 7. & Sembako & \multirow{2}{*}{$\begin{array}{l}5 \\
5\end{array}$} & \multirow{2}{*}{$\begin{array}{l}\text { Persons } \\
\text { Persons }\end{array}$} & 7.500 .000 \\
\hline 8. & Top up & & & 5.000 .000 \\
\hline 9. & Tire Repairmen & 5 & \multirow{3}{*}{$\begin{array}{l}\text { Persons } \\
\text { Persons } \\
\text { Persons }\end{array}$} & 7.500 .000 \\
\hline 10. & Food & 6 & & 6.000 .000 \\
\hline 11. & $\begin{array}{l}\text { Motor } \\
\text { Repairmen }\end{array}$ & \multirow{2}{*}{$\begin{array}{l}2 \\
65\end{array}$} & & 4.000 .000 \\
\hline Tota & & & Persons & 98.500 .000 \\
\hline
\end{tabular}

The Muslim population according to BPS (2014) in East Kalimantan is 3,277,332 people, or about $85.38 \%$. This amount is not directly proportional to the amount of zakat receipts collected by zakat institutions in East Kalimantan. Whereas zakah is supposed to be a transformation between the rich and the poor, or the person receiving the zakat can turn into a charity if the zakat is managed by the institution and by the recipient or the so-called productive zakat [13].

The magnitude of ZIS should be able to increase the income and social welfare of the mustahiq if it is channeled in a more innovative way and breakthrough, therefore Baznas Kaltim undertakes the economic empowerment program of the ummah for the mustahiq, in line with his vision of being a trustworthy and professional amil in managing ZIS, as well as its mission, namely: (1) raising zakat awareness for the muzakki, optimizing the management of trustworthy and professional ZIS. (2) increasing the status of mustahiq into muzakki through human resources improvement and human economic development program. (3) utilizing and distributing ZIS to mustahiq in a more efficient and effective manner. (4) Institutional strengthening of Regency/City Baznas in East Kalimantan. The ZIS collected by Baznas Kaltim is distributed to the poor and other asnaf, with different types of usage. ZIS accepted mustahiq poor and other asnaf used for consumptive use and productive use. The guidance program undertaken aims to improve business performance through mentoring by looking at entrepreneurial intentions and external environmental factors of mustahiq assisted.

The problem to be studied in this research is the effectiveness of productive zakat distribution as an instrument to improve business performance mustahiq. The alternative to explore the source of financing that can be done is through zakat. The ZIS collected by Baznas Kaltim is distributed and distributed to the poor and other asnaf, with different types of usage. ZIS accepted mustahiq poor and other asnaf used for consumptive purposes and productive purposes. Based on the evaluation of zakah, infaq, and shadaqah (ZIS) productive disbursements over the last few years since the inception of the related programs in 2011 to the present, efforts to improve the business performance mustahiq which further implies the increase in income, expertise, and prosperity has not achieved results the maximum. This can be seen from the failure to increase the status of mustahiq be muzakki, or in the sense that the channelling of productive ZIS has not reached its ideal destination.

Researchers want to see some problems that cause effective or not ZIS program, especially for productive ZIS, among others, quality of human resources (HR) to face external factors both competitors, technology, economy, and environment, entrepreneur spirit that is in self mustahiq receiver of zakat, and problems from the side of the mustahiq character itself.

The limitations of quality mustahiq so far both in terms of formal education and knowledge and skills are very influential on business management, so the business is difficult to develop optimally. In addition, with limited human resource quality, 
business units mustahiq relatively difficult to adopt new technological developments to improve the competitiveness of products it produces because of the lack of desire to learn and use technology. Lack of information related to the progress of science and applied technology, causing the facilities and infrastructure they have also not fast growing and less support the progress of business as expected. In addition, not infrequently difficulty in obtaining a place to run his business due to the high price of rental or business premises that are less strategic. The low entrepreneurial spirit of causing mustahiq financed by Baznas may not be able to exploit the potential and not able to innovate. Entrepreneurship is a process whereby individuals pursue opportunities that are considered to be profitable. The essence of entrepreneurship is identifying opportunities, implementing and practicing them (McLelland, 1961).

The community listed as the recipient of Baznas of Kalimantan Timur is divided into several classifications, namely; consumptive and productive mustahiq. Consumptive group is not the object of this research because it is the recipient of the consumable funds. Thus, the object of the research is productive mustahiq, in terms of business development.

Several studies indicate that the entrepreneur's spirit possessed by the recipient of zakat (mustahiq) greatly affects the success of business performance (Rahman, 2011), besides that the facilitation factor is very active role toward the pity of the mustahiq (Sartika, 2008), some variables that influence the business performance mustahiq also Very determined by the external environment such as technology and government policies that overshadow (Ulfah, 2010).

Singh and Belwal (2008) in his research through focused interviews to identify problems in the UMK sector in Ethiopia found that some components of the problem include finance to establish and run, lack of entrepreneurship, management and exposure, problems in finding markets and distribution networks. Limited opportunities for promotion and participation, limited amounts of government institutional support, knowledge of technology and integration mechanisms, and rampant corruption in the main obstacles.

Omerzel and Antoncic, (2008) model hypotheses about the relationship between entrepreneurship knowledge and performance supported or influential, thus reflecting the positive effect of entrepreneurship knowledge on all dimensions on the performance of SMEs. The study is limited to MSEs in Slovenia.

Some gaps that can be inferred from these studies are (1) it appears that there has been no specific research on the recipient of zakat and its relation to external factors and characteristics of the owner and assistance to the performance of his business; (2) all research conducted on small company (UMK) which generally have institutional ie micro business, small and not at individual effort which is micro and small; (3) there is still a difference in the concept of definition and measurement of entrepreneurship and mentoring among the research, so that it will be tried for the mustahiq group that owns micro and small business; (4) As for the research in Indonesia which specifically discuss the zakat and related to this research there are still many qualitative or theoretical studies; (5) this research will see the factor of business performance mustahiq through zakat productive.

\section{A. Business Performance of Mustahiq}

Before knowing mustahiq need to be understood first understanding Muzakki or giver of zakat. Reference [13] declares Muzakki are those who already have property or income that reaches nishab, so it is obliged to issue zakat on the property or income in accordance with the levels that have been determined by sharia in a certain time which usually counted in one year. A zakat payer is required to be Muslim and baligh or intelligent.

Mustahiq is a person entitled to receive zakat, based on the word of [1]:

1. Fakir (al fuqoro). Fakir is a very miserable person, does not work (because of certain things such as old, disabled, sick, etc.), has no treasure to fulfil the basic needs of his life such as clothing, food and boards (housing) and other essential necessities, either for themselves and their dependents. 
2. Poor (al miskiina). Poor is a person who works but not enough livelihood and in a state of deprivation.

3. Amil zakat (al amiil). The definition of Amiil is (a) the person appointed or assigned by the government to collect the zakat including the depositors, the cattle herders, and the administrators; (b) the persons who are employed in the administration of zakat affairs, both collection, maintenance, administration, And utilization, and (c) the managers of zakat or as an amil zakat institution.

4. Muallaf (al muallaf). Muallaf is a new infidant who converts to Islam where his faith is still weak and also kafir who softened his heart so as not to oppose Islam.

5. Slave (arriqob). Arriqob are those who are still in bondage and seek to escape from slavery. Slaves are also interpreted with the servant who has been promised by his master will be independent if it has paid off its self-esteem.

6. People who owe (al ghorimiin). Ghorimin is a person who owes for non-immoral interests, while he cannot afford to pay for it.

7. Fighting in the path of Allah (fisabilillah). Fisabilillah is a person who strives for the defense of Islam and the Muslims (jihad)

8. Travel far (ibnusabil / traveler), ie people who travel far with good intentions and do not do immoral, who ran out of supplies, both rich and poor in his yard.

This research is focused on the poor and the poor because the form of assistance provided both consumptive and productive so far can be given to these two asnaf, and in the other six asnaf still in consumptive form such as scholarship (ibn sabil), debt payment (ghorim), Hospital financing, and food aid (muallaf).

Reference [13] states that the poor and needy are the people in need help but can keep themselves not begging. The schools differ in meaning but with the same intentions such as the Hanafi school. The poor according to the Hanafi scholars are those who have nothing, home, money and treatment. Meanwhile, according to the imam of the three schools of jurisprudence, the so-called fakir is those who do not have the proper wealth or income in fulfilling their needs, clothing, food, shelter, and all basic necessities either for themselves or their dependent families. Poor means those who own property or income but do not meet their own needs and needs and dependents, for example ten but five or six. In the four schools it is agreed that the rich should not receive zakat.

Performance is the result or output of a process (Nurlaila, 2010: 71). According to a behavioral approach in management, performance is the quantity or quality of something produced or services provided by someone who does the work (Luthans, 2005: 165). Performance is the result or success rate of a person as a whole over a certain period of tasks compared to possible possibilities, such as predetermined work standards, predetermined targets or goals or criteria already agreed (Rivai and Basri, 2005: 50).

\section{B. External Environment}

The business environment is the dynamics of the movement of the business environment that is strongly influenced by the external environment (macro). Environmental analysis is a process of monitoring the organization's environment aimed at identifying opportunities and threats that affect the company's ability to achieve its goals. The purpose of the environmental analysis is that the organization can anticipate the environment, so it can react quickly and appropriately for the success of the organization (Dirgantoro, 2001).

The external environment of an enterprise is the factors outside the firm that affect the company's ability to operate. Some external elements can be manipulated by the company, while others require an adjustment effort from the organization. A business converts inputs into outputs in order to gain profit. The external environmental factors that influence a business according to Williams (2001: 51) are: 1) competitors, 2) economic system, 3) social system, 4) monetary system, 5) political/ legal system, 6) environmental system, and 7) technology Changes.

Competitors affect the ability of businesses to generate profits, because competitors will continue to seek to gain more from each other, by differentiating their products and services, and by trying to provide better value for money. The economic system is an economic organization to 
allocate scarce resources. The economy tends to go through a period of faster and slower growth. Businesses prosper when the economy is booming and living standards are rising.

The relationship between the business environment and entrepreneurship is explained by Abimbola and Agboola (2011) which suggests that the environment is covering factors such as infrastructure, community culture, economic, social, and political environment. Environmental forces have been found to inhibit or facilitate the entrepreneurial activities of any community. Gnyawali and Fogel (1994) define the external environment of entrepreneurship as "the whole socio-cultural and political economic factors that influence

\section{METHODS}

The study is qualitative research. There are eight informants in this study. It can be shown by the table below.

TABLE III

The ReCIPIENT OF BAZNAs MustahIQ ON Productive ZAKat IN 2016

\begin{tabular}{|c|l|l|l|r|}
\hline No & \multicolumn{1}{|c|}{ Name } & $\begin{array}{l}\text { Asnaf } \\
\text { Type }\end{array}$ & $\begin{array}{c}\text { Type of } \\
\text { business }\end{array}$ & $\begin{array}{c}\text { The amount } \\
\text { of } \\
\text { distribution }\end{array}$ \\
\hline 1 & $\begin{array}{l}\text { Tafaqquh } \\
\text { Fiddin XXII }\end{array}$ & Poor & $\begin{array}{l}\text { Coopera } \\
\text { tion }\end{array}$ & 17.925 .000 \\
\hline 2 & $\begin{array}{l}\text { Yusuf } \\
\text { Qordhowi }\end{array}$ & Poor & $\begin{array}{l}\text { Course } \\
\text { Place }\end{array}$ & 8.500 .000 \\
\hline 3 & $\begin{array}{l}\text { Pre- } \\
\text { Prosperous } \\
\text { Family 1 }\end{array}$ & Poor & Grocery & 5.000 .000 \\
\hline 4 & $\begin{array}{l}\text { Pre- } \\
\text { Prosperous } \\
\text { Family 2 }\end{array}$ & Poor & Grocery & 5.000 .000 \\
\hline 5 & $\begin{array}{l}\text { Pre- } \\
\text { Prosperous } \\
\text { Family 3 }\end{array}$ & Poor & Food & 5.000 .000 \\
\hline 6 & $\begin{array}{l}\text { Pre- } \\
\text { Prosperous } \\
\text { Family 4 }\end{array}$ & Poor & Food & 5.000 .000 \\
\hline 7 & $\begin{array}{l}\text { Pre- } \\
\text { Prosperous } \\
\text { Family 5 }\end{array}$ & Poor & Food & 5.000 .000 \\
\hline 8 & Kiki Fitriani & Poor & Food & 2.000 .000 \\
\hline & Total & & 53.425 .000 \\
\hline
\end{tabular}

\section{RESULTS}

From the results of the study it was found that initially one group of tafaqquh fiddin and 7 recipients receiving zakat funds from Baznas were very dependent on the aid, but they were still doing the business manually without exploring more in advance of existing technology due to the limitation of resources. For instance, they do not have high education, old age, and environment that do not support the development of their business performance. In addition, it can be proved from taffaquh fiddin:

Loans from the cooperatives in the form of wheat, butter, eggs and other cake ingredients I can manage, which in a month I return on time even with the benefits to help increase cooperative funds". In addition to the cake I'm selling in front of the house, I divide the stalls and work with the company around the residence to become a provider (supplying) the cake at certain times in the company (entrepreneurship), so it helps increase my income (business performance) (taffaquh fiddin)

Based on the statement above, it can be seen that taffaquh fiddin is a poor person who got the aid from the BAZNAS but he can become productive through the aids. Mr. Yusuf Qardhawi is another informant also get aids, said:

Zakat funding aid I use to help the business that has been running the guidance of learning, before I just received tutoring at home with the help now I have a used motor to increase my income so mock, then I can also home-school students to guide them. From that result I can give infaq routine to Baznas.

Based on the statements above, it can be concluded that taffaquh fiddin and $\mathrm{Mr}$ Yusuf Qardhawi have a strong entrepreneurship spirit in doing the business. However, they do not have enough resources in technological, economic, and cultural factors. This is not in line with the theory that technological, economic, and cultural factors significantly influence the performance of economic enterprises (Buse \& Hefeker 2007); 
Socio-cultural (Shapero \& Sokol 1982, Gianneti \& Simonov 2003). And this is in line with previous research which states that Economic, political, technological and socio-cultural laws cannot directly influence business performance unless they have to go through entrepreneurial factors first (Wheelend, 2003), (Umar 2005).

\section{IV.DISCUSSION}

Furthermore, the results of research also found that it is very important that mentoring encourages entrepreneurship spirit in terms of improving their business performance. Indeed, the assistance or facilitator can provide the solution that will solving their problems. For instance, Pre Prosperous Family 2 stated :

I have been selling seaweeds and fish crackers, with the help of productive zakat funds I expand my business to sell bekang empek-empek typical, although many rivals but with the help of mentoring from baznas I can work with traveltravel to promote my empek-empek to the guests, so this can add to my business income, now I can add my business again by selling fish balls, I am grateful to the mentoring because I was able to use social media (online) in market my sales.

Based on the statement above, it can be concluded that mentoring has important role in guiding the poor to solve the problem in technology. In the spirit of entrepreneurship there must be trust, commitment, support of the nearest person, communication openness, incentive to seek opportunity (Wood, Mcdermot, Swan 2002). The communication between mentoring and the beneficiaries can make good communication to improve the entrepreneurship spirit.

Furthermore, the training of skills and knowledge can improve the business performance. The poor family from Samarinda is a widdow which becomes a laundry from one house to another house. Pre-Prosperous Family 5 asserted:

I am a widow which has two children. I become a laundry girl from one house to another house. The fund of Baznas which is given to me becoming a equity to make catering. They give us training how to improve the skill in financing.
Alhamdullilah ... right now, I can give infaq to BAZNAS even it is only Rp. 50.000 [per month]..

Based on the statement above, it can be drawn that training from baznas can help them in improving their business performance. This is in line with previous research that training and facilitation is the improvement of skills and knowledge, technological understanding, technical understanding, innovation, creativity, effectiveness that is needed in improving business performance (Noe, Hollenbeck, Gerhart, Wright (2003). However, several informants have not been able to maximally manage themselves to be more creative so that the mustahiq cannot be able to improve their business performance.

\section{CONCLUSIONS}

Based on the explanation above, it can be concluded that every business actor is required to entrepreneurial spirit, because with the spirit and creativity will greatly assist our efforts in the face of competitors and the progress of an increasingly complex era.

Furthermore, mustahiq recipients of zakat funds have not all have entrepreneurial spirit, and have not been able to use technology in order to be defeated by competitors, this is because in addition to the education is still minimal, also their understanding with the increase in living standards is also different, there are many who prefer to expect assistance rather than giving help. It can be suggested that better mentoring more intensively and done by successful entrepreneurs first, in order to stimulate the spirit and motivation mustahiq to creative and innovate in the effort.

Moreover, the aim of productive zakat should be done gradually after the aid of consumptive zakat given, because if directly given productive zakat but their primary needs have not been met then it will be spent on their stomach needs first, and productive assistance will be not exactly the purpose and purpose.

\section{REFERENCES}

[1] Al-Quran dan Al-Hadist

[2] Achmad Faisal, S.Pd Buku Petunjuk Zakat Praktis Karya:

[3] Wawan Shofwan Shalehuddin Buku Risalah Zakat Infak \& Sedekah Karya 
[4] Elsi, Kartika. (2006). Pengantar Hukum Zakat dan Wakaf. Jakarta, PT Grasindo.

[5] Gordon, Thomas. (1994). Menjadi Pemimpin Efektif: Dasar untuk Manajemen Partisipatif dan Keterlibatan Karyawan. Terjemahan Alex Tri Kantjono Widodo. Jakarta : Gramedia Pustaka Utama.

[6] Jogiyanto, H. (2007). Metodologi Penelitian Bisnis. Yogyakarta, BPFE: Cetakan Pertama.

[7] Kurniawan, Beni. (2009). Pendidikan Agama Islam untuk Perguruan Tinggi. Jakarta: Grasindo.

[8] Mangkunegara, Anwar Prabu. (2001). Manajemen Sumber Daya Manusia. Bandung, Remaja Rosdakarya.

[9] McDougall, P Phillips. and Benjamin, M. Oviatt. (2000). International Entrepreneurship: The Intersection of Two Research Paths. The Academy of Management Journal, 43 (5), 902-906.

[10] Suharto, Edi. (1997). Pembangunan, Kebijakan Sosial dan Pekerjaan Sosial: Spektrum Pemikiran. Bandung: Lembaga Studi PembangunanSTKS.

[11] (2004). Social Welfare Problems and Social Work in Indonesia: Trends and Issues. (Masalah Kesejahteraan Sosial dan Pekerjaan Sosial di Indonesia: Kecenderungan dan Isu). International Seminar on Curriculum Development for Social Work Education in Indonesia. Bandung: Sekolah Tinggi Kesejahteraan Sosial.

[12] (2004), Kemiskinan dan Keberfungsian Sosial: Studi Kasus Rumah Tangga Miskin di Indonesia. Bandung: STKSPress.

[13] Qordhowi, Yusuf. (2011). Hukum Zakat: Studi Komparatif Mengenai Status dan Filsafat Zakat Berdasarkan Quran dan Hadist. Translate by Salman. Harun. Didin, Hafidhuddin. Hasanuddin. Litera Antar Nusa: Pustaka Nasional. 